\title{
Laterality and its influence on the written expression of intellectually disabled pupils
}

\author{
[Lateralita a jej vplyv na pisomny prejav ziakov s mentalnym \\ postihnutim]
}

\author{
Monika Sulovska - Alica Vancova - Natalia Neupauerova
}

DOI: 10.18355/XL.2019.12.04.11

\begin{abstract}
The paper presents the results of research into the formal aspect of writing skills and writing in pupils with mild intellectual disability to laterality. This exploratory study aims to conclude the results from qualitative analysis of the lettering (shape, size, proportionality, unity, and gradient of letters) and assessment of adherence to the technical requirements of writing (holding writing instruments and body position by writing). The sample consisted of twenty pupils with mild intellectual disabilities aged 12-14 years (ten pupils with dominant left hand and ten pupils with dominant right hand) attending special primary schools in Bratislava region and Košice region. We analyzed 60 font samples in the form of depreciation, transcription, and dictation. The research results point to the difference in the quality of the written expression of pupils with intellectual disabilities, where the pupils with the dominant left hand have achieved better results in most qualitative fonts. In both groups, pupils achieved the best results in the form of a transcript, with the least difficulty in maintaining unanimity, and the greatest problems for the pupils were keeping the correct shape and proportionality of the letters. In the framework of technical requirements of writing, 17 pupils detected incorrect posture while writing, while six pupils detected incorrect grasp of writing tools.

The results of research in pupils with a dominant left hand showed that the recommended method of writing left-handers was not followed. We appeal to the importance of the methodology of writing for pupils with intellectual disabilities, where a properly guided methodological approach of the teacher plays an important role.
\end{abstract}

Key words: laterality, left-handed, handwriting, the pupil with intellectual disability, written expression, quality of writing

\section{Anotácia}

V článku prezentujeme výsledky výskumu formálnej stránky písomného prejavu a písania žiakov s l'ahkým stupňom mentálneho postihnutia z apsektu laterality. Predmetom výskumu bola analýza kvalitatívnych znakov písma (tvar, vel'kost', úmernost', jednot'ažnost' a sklon písmen) a posudzovanie dodržiavania technických požiadaviek písania (úchop písacieho náčinia a poloha tela pri písaní). Výberový súbor tvorilo dvadsat' žiakov s l'ahkým stupňom mentálneho postihnutia vo veku 12 . - 14. rokov (10 žiakov s dominantnou l'avou rukou a desat' $s$ dominantnou pravou rukou) navštevujúcich špeciálne základné školy v Bratislavskom a Košickom kraji. Analyzovaných bolo 60 vzoriek písma vo forme odpisu, prepisu a diktátu. 
Výsledky výskumu poukazujú na rozdiel v kvalite písomného prejavu žiakov s mentálnym postihnutím, kde žiaci s dominantnou l'avou rukou dosiahli vo väčšine kvalitatívnych ukazovatel'ov písma lepšie výsledky. V oboch skupinách dosiahli žiaci najlepšie výsledky vo forme prepisu, najmenšie problémy mali s dodržaním jednot’ažnosti a najväčšie problémy pre žiakov predstavovalo doržiavanie správneho tvaru a úmernosti písmen. V rámci technických požiadaviek písania bolo u 17 žiakov detegované nesprávne držanie tela pri písaní, u šiestich žiakov nesprávny úchop písacieho náčinia.

Výsledky výskumu u žiakov s dominantnou l'avou rukou poukázali na nejednotnost' a nedodržiavanie odporúčaného spôsobu písania l'avákov. Apelujeme na význam metodiky písania u žiakov s mentálnym postihnutím, kde dôležitú úlohu zohráva správne vedený metodický postup učitel'a.

Kl'účové slová: lateralita, l'aváctvo, rukopis, žiak s mentálnym postihnutím, písomný prejav, kvalita písma

\section{Úvod}

Vediet' samostatne písomne komunikovat' je podl'a Vzdelávacieho programu pre žiakov s mentálnym postihnutím pre primárne vzdelávanie (ŠPÚ, 2016) jednou z kl'účových kompetencií, od zvládnutia ktorej sa odvíja úspešnost' žiakov v procese d'alšieho učenia sa. V našom výskumnom pracovisku sme sa výskumnej analýze písomného prejavu žiakov s mentálnym posithnutím venovali vo viacerých prácach, spomenieme preto len niektoré. Vo výskume Ordódyho (2008) pod vedením PhDr. Petra Pavlisa, CSc. boli analyzované vzorky písma z diktátu, prepisu a opisu 66 žiakov (22 žiakov špeciálnej základnej školy a 44 žiakov bežnej základnej školy). Autori zistili, že žiaci špeciálnej základnej školy v 3. ročníku zaostávali za intaktnými žiakmi 1. ročníka základnej školy. V nadväznosti na spomínaný výskum Avante (2009) takisto pod rovnakým vedením realizovala výskum u týchto žiakov s časovým odstupom jedného roka (4. ročník špeciálnej základnej školy). Výsledky výskumu hovoria o zlepšení všetkých ukazovatel'ov písma, avšak nie v rovnakej miere ako u žiakov intaktných. Ciel'om výskumu Šulovskej, Miláčkovej (2016) bolo analyzovat' písomný prejav žiakov s l'ahkým stupňom mentálneho postihnutia z grafickej, gramatickej i technickej stránky. Analyzovaných bolo 54 vzoriek písma (odpis, prepis, diktát) od 9 participantov vo veku 11-12 rokov, ktorí boli vtom čase vzdelávaní v podmienkach špeciálnej základnej školy. Predmetom výskumu bola analýza kvalitatívnych znakov písma, posudzovanie dodržiavania technických požiadaviek písania a chybovost’ písaného textu. Výsledky výskumu ukázali, že bez ohl'adu na príslušnost' $\mathrm{k}$ forme písomného prejavu, bola detegovaná vyššiu početnost' chýb $\mathrm{v}$ diakritike a v interpunkcii. Majoritne sa vyskytujúcim javom $\mathrm{v}$ rámci technických požiadaviek písania bola $\mathrm{u}$ participantov zmenšená vzdialenost' hlavy od písacej plochy. Písmo participantov bolo oproti normou odporúčaným hodnotám zväčšené, bola nedodržaná jednot’ažnost' a nedostatočne zvládnutá úmernost' písmen.

Sú rozdiely v písomnom prejave u žiakov s mentálnym postihnutím v súvislosti s ich laterálnou preferenciou? Analýzou dostupných výskumných prác v rámci Slovenskej republiky takéto výskumné riešenia absentujú. 


\section{Teoretické východiská}

Lateralita je prejavom dominancie jednej z mozgových hemisfér. Špeciálnopedagogický slovník od Zikla a Bendovej (2014) ju definuje ako prednostné užívanie jedného z párových orgánov a podobne Sillamy (2001) ako funkčnú prevahu jednej strany l'udského tela nad druhou, ktorá sa prejavuje zvlášt' $\mathrm{v}$ prednostnom využívaní jedného oka alebo končatiny $\mathrm{k}$ vykonávaniu úloh vyžadujúcich určitú presnost'. Viacerí autori (Matějček, Žlab, 1972; Sovák, 1979; Drnková, Syllabová, 1983; Healey, 2002; Vodička, 2008 a iní) vo svojich publikáciách uvádzajú pät' stupňov laterality, napr. podla Drnkovej, Syllabovej (1983): L (vyhranené, výrazné l’aváctvo), L- (menej vyhranené, mierne l'aváctvo), A (nevyhranená lateralita), P- (menej vyhranené, mierne praváctvo), P (vyhranené, výrazné praváctvo). Podla Přinosilovej (1997) a Fasnerovej (2018) sa u väčšiny intaktnej populácie vyhraňuje lateralita medzi 3. a 4. rokom života jednotlivca. V prípade onekoreného vyhranenia laterality považujú autorky za akceptovatel'né oneskorenie do veku 10. rokov. $\mathrm{Aj} \mathrm{z}$ tohto dôvodu a rešpektujúc oneskorený vývin jednotlivcov s mentálnym postihnutím, zaradili do nášho výskumného súboru žiakov starších ako 12 . rokov. Vodička (2008) uvádza v súvislosti s lateralitou najčastejšie problémy pri písaní práve u žiakov s dominantnou l'avou rukou. Proces výučby písania však nezáleží podl'a Spáčilovej a Šubovej (2004) len od dispozícií a spôsobilostí samotného žiaka, ale aj od správne metodicky vedeného prístupu učitel'a.

I ked' množstvo žiakov s dominanciou l'avej ruky je približne $10 \%$ z celkovej populácie, uplatnenie jednotnej metodiky nie je natol'ko jednoznačné ako u jednotlivcov, u ktorých je dominantná ruka pravá. Preto $\mathrm{v}$ súčasnosti dochádza $\mathrm{k}$ rozporuplným teóriám, ktoré zaujímajú iné stanoviská a názory na metodiku písania l'avákov (Fasnerová, 2018; Valenta, Michalík, Lečbych a kol., 2018). Synek (1991) označuje metodiky písania žiakov s dominanciou l'avej ruky ako nedokonalé, pretože sú tvorené len z poznatkov písania žiakov dominantne pravorukých.

Po podrobnej analýze písania jednotlivých grafém malej abecedy výsledky poukazujú na výrazné rozdiely $\mathrm{v}$ možnostiach písania žiakov s rôznou dominanciou horných končatín. Pravák pri písaní využíva pohyb t’ahom, v percentuálnom zastúpení $91,9 \%$, u písmen vel'kej abecedy je výsledok o niečo nižší a síce $90,45 \%$. Písaný tvar grafém je z dôvodu napájania písmen konštruovaný pre pohyb t’ahom, čo je pre l'avákov píšucich dolným spôsobom neprijatel'né. V uvedenom prípade žiaci s dominantnou l'avou rukou využívajú viac tlakových pohybov a menej t’ažných, písanie sa tak pre laváka stáva fyzicky namáhavou činnostou. $\mathrm{Z}$ uvedených dôvodov si žiaci napomáhajú hákovitým držaním písacieho nástroja, tzv. horným spôsobom, pomocou ktorého sa dokážu priblížit' k spôsobu písania pravákov (Vodička, 2008; Fasnerová, 2018; Mlčáková, 2009). Vodička (2008) rozdeluje žiakov s dominantnou l'avou končatinou podl'a polohy ruky pri písaní na píšucich dolným spôsobom písania a píšucich horným spôsobom písania tzv. hákovitým držaním.

Pišuci lavák by mal zaujat' pozíciu, ktorá súhlasí s protil'ahlým obrazom praváka. Žiak by mal mat' pri písaní lakte súmerne opreté o lavicu. Hlava a ani zvyšok tela by nemal byt' vychýlený do strán. Dôležité je, aby bola ruka 
v zápästí uvol'nená, tak aby dlaň bola položená na lavici a váha tela sa z časti presúvala na predlaktie. Prsty ruky by mali počas písania zotrvat' pod líniou, aby si žiak nezakrýval písaný text. Pero by malo byt' držané tak, aby sa dostávalo do polohy zarovno s linkou, ako aj do kolmej polohy smerom zhora. Úchop písacieho náčinia by mal byt' zo strany alebo proti sebe (Sovák, 1971; Matějček, Žlab, 1972; Křrišt'anová, 1998).

Vodička (2008), Healey (2002), Holle (2011) vyvracajú názor staršej generácie autorov, že hákovitý spôsob písania je pomalší a zápästie nie je pri písaní správne používané. Zastávajú názor, že uvedený spôsob písania je pre l'avákov najviac zhodnou podobou, kedy má žiak presný náhl'ad na práve písaný text.

Písacie náčinie žiak drží v l'avej ruke, rovnakým spôsobom ako pravák, hrot mieri k l’avému ramenu, predlaktia sú kolmo k riadku (Sovák, 1979).

Za vhodnú polohu zošita, u žiakov píšucich l'avou rukou, považujú Křišt’anová (1998) a Sovák (1979) umiestnenie zošita na lavici mierne vl'avo od osi tela. L'avý horný roh zošita smeruje mierne nahor, u l'avákov však akceptujeme individuálny sklon písma.

U žiakov s preferenciou l'avej ruky, nachádzame viacnásobne väčšiu variabilitu polohy zošita, z dôvodu hl'adania cesty ako si písmo vytvorené pre pravákov, čo najlepšie prispôsobit'. Papier by mal byt' pridržiavaný pravou rukou položenou bližšie k pravému okraju zošita, nie priamo pod riadkom (Healey, 2002; Vodička, 2008).

Po dôkladnom preštudovaní problematiky metodiky písania žiakov s dominanciou l'avej ruky, si dovolíme tvrdit', že odporúčaná metodika je nepostačujúca. Stotožňujeme sa s názorom Healey (2002), Mlčákovej (2009), Vodičku (2008) a Fasnerovej (2018), že vhodnú metodiku písania žiakov s dominanciou l'avej hornej končatiny je potrebné aktualizovat' o poznatky pedagogickej praxe.

\section{Ciel' výskumu a výskumné otázky}

Ciel'om výskumu bolo analyzovat' písmo a písanie žiakov s l'ahkým stupňom mentálneho postihnutia s rôznou laterálnou preferenciou. Zistit', či existujú rozdiely $\mathrm{v}$ písomnom prejave žiakov s rôznou laterálnou dominanciou a zároveň pozorovaním technických požiadaviek písania overit' dodržiavanie stanovenej metodika písania u oboch skupín.

Vychádzajúc zo získaných teoretických poznatkov sme si pred začatím výskumnej činnosti stanovili nasledovné výskumné otázky:

Výskumná otázka č.1: V čom sa odlišujú vzorky písma jednotlivých laterálne diferentných participantov?

Výskumná otázka č.2: Aký spôsob písania je preferovaný u l'avákov?

Výskumná otázka č.3: Do akej miery dodržiavajú žiaci pri písaní technické požiadavky?

\section{Výskumné metódy}

Pri výskumnej činnosti zist'ovania vplyvu laterality na písomný prejav žiakov s l'ahkým mentálnym postihnutím sme vzhl'adom na získanie potrebných dát a dosiahnutie stanovených ciel'ov uplatnili nasledovné výskumné metódy: Metóda participačného pozorovania

XLinguae, Volume 12, Issue 4, October 2019, ISSN 1337-8384, eISSN 2453-711X 
Zvolená metóda bola uplatnená v dôsledku zvýšenej objektívnosti, konkrétne pri prepise, odpise a diktáte, ktorý sme žiakom pripravili formou pracovného listu. Počas práce žiakov sme pristúpili k fotografickému zaznamenávaniu pre lepší záznam o dodržiavaní technických požiadaviek, rovnako aj písomnému zaznačeniu v prípade špecifických prejavov písania. Všetky získané informácie sme uplatnili pri osobitnom kvalitatívnom hodnotení písomného prejavu participantov v d’alších častiach výskumu.

Metóda analýzy výsledkov činnosti

Pre objektívnost' hodnotenia vzoriek písma sme zostavili jednotné pracovné listy s textom a linajkami. Texty použité $\mathrm{v}$ pracovných listoch boli vybrané z učebníc pre špeciálne základné školy. Po vyzbieraní sme vzorky písma analyzovali a v programe Microsoft Excel sme vytvorili prehl’adnú databázu žiakov s nami nameranými hodnotami. Pomocou usporiadaných dát sme následne mohli prejst' $\mathrm{k}$ ich komparácii.

Vo výskume sme sa zamerali na kvalitatívne ukazovatele písma žiakov s mentálnym postihnutím, konkrétne na vel'kost' a úmernost' písmen, jednot'ažnost', tvar, sklon, celkovú úpravu grafického prejavu, čitatel'nost' písma a dodržiavanie liniatúry. Pri stanovení kritérí hodnotenia sme vzhliadali k uvedeným kvalitatívnym znakom písma publikovanými autormi Šupšáková (1998), Pavlis (1989), Fasnerová (2018), Mlčáková (2009).

Okrem spomenutých kvalitatívnych ukazovatel'ov bolo predmetom nášho záujmu aj dodržiavanie technických požiadaviek písania. Pre možnost' posudzovania vzoriek písma sme si stanovili nasledovné kritéria posudzovania písomného prejavu:

- Numerické kriteriálne vyjadrenie sme použili pri ukazovatel'och vel'kosti a sklonu písma použitím pravítka a uhlomeru. Namerali sme samostatne vel'kost' písmen strednej výšky, hornej dížky, dolnej dížky a hornej a dolnej dížky, následne sme hodnoty spriemerovali a zaznamenali do databázy.

- Škála s piatimi stupňami hodnotenia bola uplatnená pri zaznamenávaní jednotažnosti, tvaru, úpravy grafického prejavu, čitatel'nosti písma a dodržiavaní liniatúry. V rozmedzí piatich stupňov, bolo číslom 1 hodnotenie javu, ktoré spíňalo všetky požadované kvalitatívne nároky a číslom 5 bol označený jav, ktorý nedostatočne až absolútne nezodpovedal požadovaným kvalitatívnym nárokom. Pre hodnotenie úmernosti sme zvolili tiež škálu s piatimi stupňami, avšak stupňom 1 sme označili odchýlku $0,10 \mathrm{~cm}$, stupeň 2 tvorila odchýlka $0,20 \mathrm{~cm}$ od normy. Rovnako sme postupovali až do stupňa č. 5 , kde sme zahrnuli aj odchýlky rovné a väčšie ako $0,5 \mathrm{~cm}$.

\section{Výberový súbor}

Vzhl'adom na nižší počet žiakov s dominanciou l'avej hornej končatiny sme zber dát vykonávali vo viacerých etapách $\mathrm{v}$ špeciálnych základných školách Bratislavského a Košického samosprávneho kraja. Výberovú vzorku (Tabul'ka č.1) tvorilo 10 žiakov s dominantnou pravou rukou a 10 žiakov s dominantnou rukou l'avou vo veku 12. - 14. rokov. Súbor pravákov tvorilo 5 chlapcov a 5 dievčat, rovnako ako súbor zložený z dominantne lavorukých, členený na 5 chlapcov a 5 dievčat. 
Tabul'ka 1 Výberový súbor

\begin{tabular}{ccccc}
\hline Participant & $\begin{array}{c}\text { Dominancia } \\
\text { hornej } \\
\text { končatiny }\end{array}$ & Pohlavie & Vek & Kraj \\
\hline 1. & pravá & $\mathrm{CH}$ & 14 & $\mathrm{KE}$ \\
2. & pravá & $\mathrm{CH}$ & 13 & $\mathrm{KE}$ \\
3. & pravá & $\mathrm{CH}$ & 13 & $\mathrm{KE}$ \\
4. & pravá & $\mathrm{CH}$ & 13 & $\mathrm{KE}$ \\
5. & pravá & $\mathrm{CH}$ & 13 & $\mathrm{KE}$ \\
6. & pravá & $\mathrm{D}$ & 14 & $\mathrm{KE}$ \\
7. & pravá & $\mathrm{D}$ & 14 & $\mathrm{KE}$ \\
8. & pravá & $\mathrm{D}$ & 14 & $\mathrm{KE}$ \\
9. & pravá & $\mathrm{D}$ & 13 & $\mathrm{KE}$ \\
10. & pravá & $\mathrm{D}$ & 12 & $\mathrm{BA}$ \\
11. & l'avá & $\mathrm{CH}$ & 13 & $\mathrm{BA}$ \\
12. & l'avá & $\mathrm{CH}$ & 13 & $\mathrm{KE}$ \\
13. & l'avá & $\mathrm{CH}$ & 14 & $\mathrm{KE}$ \\
14. & lavá & $\mathrm{CH}$ & 14 & $\mathrm{KE}$ \\
15. & l'avá & $\mathrm{CH}$ & 12 & $\mathrm{KE}$ \\
16. & lavá & $\mathrm{D}$ & $\mathrm{KE}$ \\
17. & l'avá & $\mathrm{D}$ & $\mathrm{B}$ & $\mathrm{KA}$ \\
\hline 18. & lavá & $\mathrm{D}$ & 13 & \\
19. & l'avá & $\mathrm{D}$ & 13 & 14 \\
20. & l'avá & $\mathrm{D}$ & 14 & \\
\hline
\end{tabular}

\section{Organizácia a priebeh výskumu}

Výskum prebiehal v rozmedzí mesiacov február - marec 2019 v špeciálnych základných školách v Bratislavskom a Košickom kraji. Po telefonickom dohovore s riaditel’om školy, sme si dohodli termín pre zber výskumných dát. $\mathrm{V}$ uvedenom čase nám vedenie škôl poskytlo samostatnú miestnost' pre individuálnu prácu s vybranými žiakmi. Aj ked' už žiaci boli zo strany pedagógov vopred informovaní o zapojení sa do výskumu, žiakom sme sa predstavili a oboznámili sme ich s dôvodom nášho stretnutia. Po úvodnom oboznámení sme podišli $\mathrm{k}$ vysvetleniu d’alšieho postupu. Žiakom sme pripravili rovnaké hárky s textami a riadkami zameranými na prepis, odpis a diktát. Text, s ktorým sme pracovali, si žiaci mali možnost' najskôr prečítat'. Na záver sme sa uistili, či žiaci zadaniu rozumejú. Pre objektívnost' testovania sme do písania žiakov nijakým spôsobom nezasahovali ani ich nenapomínali, počas písania sme si vyhotovovali písomné a fotografické záznamy. Ako prvý sme zadávali diktát, ktorý sme najskôr prečítali celý a následne po jednotlivých vetách. V prípade, že žiak nejakému slovu nerozumel, slovo sme zopakovali. Na záver sme žiakom diktát prečíali celý. Následne žiaci pokračovali prepisom a opisom textu. Po získaní dát vybraného súboru žiakov sme pristúpili ku kvalitatívnemu individuálnemu zhodnoteniu písomného prejavu každého žiaka, ktoré sme zapisovali do prehl'adných tabuliek. V záverečnej fáze sme získané dáta komparovali na základe stanovených výskumných otázok.

\section{Etické aspekty výskumu}

Vzhl'adom na prijatie nových nariadení Európskeho parlamentu a rady EÚ 2016/679 o ochrane fyzických osôb pri spracúvaní osobných údajov a prijatím nového zákona o ochrane osobných údajov č. 18/2018 Z.z., sme pri oslovovaní škôl zaradených do sústavy škôl školských zariadení postupovali

XLinguae, Volume 12, Issue 4, October 2019, ISSN 1337-8384, eISSN 2453-711X 
podl'a vyššie uvedeného zákona a dôsledne sme dodržiavali uvedené právne predpisy.

Pred začatím výskumu sme sa na školy obrátili s požiadavkou o písomné stanovisko o vykonaní výskumnej činnosti, ktorá bude prebiehat' v rámci výchovno-vzdelávacieho procesu. Vedenie školy sme oboznámili o všetkých aspektoch výskumu, taktiež aj o našich ciel'och. Následne sme s pomocou vedenia školy oslovili zákonných zástupcov maloletých žiakov o informovaný súhlas, ktorým umožnili participáciu ich diet'at’a na výskume a spracovanie osobných údajov žiaka.

Vzhl'adom na uvedené, v našom výskume pri označovaní žiakov používame čísla, podl'a ktorých nie je možná identifikácia žiaka, takisto neuvádzame ani názvy škôl či mestá, v ktorých sa školy nachádzajú.

\section{Výsledky výskumu}

Interpretáciu výsledkov výskumu prezentujeme v súvislosti so stanovenými výskumnými otázkami.

Výskumná otázka č. 1: V̌̌om sa odlišujú vzorky písma jednotlivých laterálne diferentných participantov?

Vel'kost' písmen určujú podl'a Penca (1961) dva javy a to výška a šírka písmena, chápeme ju ako kolmú vzdialenost' krajných bodov písmen od základnej linky alebo od základu mysleného riadku, v prípade nelinajkovaného zošita. Šírku písmen je vel'mi náročné určit', vzhl'adom na diferentnost' jednotlivých tvarov písmen. Existuje však istý ,normatívny“ pomer šírky $\mathrm{k}$ výške $2: 3$. V našom výskume sme sa zamerali len na výšku písmen.

Tabul'ka 2 Komparácia priemerných hodnôt vel'kosti písmen u oboch skupín

\begin{tabular}{|c|c|c|c|c|}
\hline \multicolumn{5}{|c|}{ Priemerné namerané hodnoty vel'kosti písmen } \\
\hline \multicolumn{5}{|c|}{ lateralita pravá } \\
\hline & $\begin{array}{c}\text { písmená so } \\
\text { strednou výškou } \\
\text { norma }(0,3-0,4)\end{array}$ & $\begin{array}{l}\text { písmená s dolnou } \\
\text { dížkou } \\
\text { norma }(0,6-0,8)\end{array}$ & $\begin{array}{c}\text { písmená s hornou } \\
\text { dížkou } \\
\text { norma }(0,6-0,8)\end{array}$ & $\begin{array}{l}\text { písmená s hornou } \\
\text { aj dolnou dížkou } \\
\text { norma }(0,9-1,2)\end{array}$ \\
\hline prepis & 0,39 & 0,60 & 0,67 & 0,82 \\
\hline odpis & 0,37 & 0,65 & 0,81 & / \\
\hline diktát & 0,37 & 0,57 & 0,74 & / \\
\hline \multicolumn{5}{|c|}{ lateralita l'avá } \\
\hline & $\begin{array}{c}\text { písmená so } \\
\text { strednou výškou } \\
\text { norma }(0,3-0,4)\end{array}$ & $\begin{array}{l}\text { písmená s dolnou } \\
\text { dížkou } \\
\text { norma }(0,6-0,8)\end{array}$ & $\begin{array}{l}\text { písmená s hornou } \\
\text { dížkou } \\
\text { norma }(0,6-0,8)\end{array}$ & $\begin{array}{l}\text { písmená s hornou } \\
\text { aj dolnou dížkou } \\
\text { norma }(0,9-1,2)\end{array}$ \\
\hline prepis & 0,38 & 0,72 & 0,78 & 1,16 \\
\hline odpis & 0,40 & 0,72 & 0,78 & $/$ \\
\hline diktát & 0,35 & 0,64 & 0,76 & / \\
\hline
\end{tabular}

V tabul'ke č. 2 sú obsiahnuté dáta získané aritmetickým priemerom. Podl'a získaných dát žiaci píšuci pravou rukou dodržiavajú vel'kost' písmen so strednou výškou (vo všetkých vzorkách sa hodnota pohybuje v stanovenom intervale). U písmen s dolnou dížkou hodnotíme zhodnú situáciu, až pri vzorke diktátu, kde väčšina žiakov svoje písmo zmenšila a výsledná hodnota nedosahovala stanovené kritérium. Prijatel'ný výsledok žiaci dosiahli aj v písaní písmen $\mathrm{s}$ hornou dížkou, kde sa tiež pohybujú v stanovenom 
rozmedzí. Negatívny výsledok dosiahli praváci vo vel'kosti písmen s hornou a dolnou dížkou, kde je výsledná hodnota nižšia ako požadované kritérium. U žiakov s dominantnou l'avou rukou je interval vel'kostí písmen dodržiavaný vo všetkých vzorkách. V nami hodnotených vzorkách neevidujeme medzi l'avákmi a pravákmi exaktné rozdiely vo vel'kostiach písmen jednotlivých skupín.

Sklon písmen chápeme ako uhol zvierajúci os písmen s linkou alebo myslenou základnou čiarou na nelinkovanom papieri. Uhol overujeme po pravej strane osi písmena. Podl’a Šupšákovej (1998), Fasnerovej (2018) je správny uhol pri písaní 70 až $75^{\circ}$. V našom výberovom súbore sme v oboch skupinách zaznamenali nedodržiavanie správneho sklonu - priemerná hodnota žiakov s dominantnou pravou rukou dosiahla $58^{\circ}$. Dominantne l'avorukí žiaci majú sklon písma v priemere $65^{\circ}$, čo je zároveň bližšie norme.

Čitatel'nost' a úhl'adnost' grafického prejavu ovplyvňuje aj samotná úprava, správne rozvrhnutie plochy papiera, ako aj usporiadanie textu na ňom. Zásluhu na grafickej úprave má najmä psychický stav jednotlivca, rovnako tak spoločnost', v ktorej sa žiak pohybuje (Šupšáková, 1998).

Fasnerová (2018) doplńa pravidlá, ktoré by mali byt' v úhl'adnom texte aplikované. Žiaci by mali mat' v zošitoch rovnaké okraje, nadpisy a texty prvého riadku by mali písat' v dvojnásobnej vzdialenosti. Učitel' má žiakov podporovat' v udržiavaní čistoty a úhl'adnosti v zošitoch, nie len pri písaní, ale aj pri prepisovaní a gumovaní (Penc, 1968; Šupšáková, 1998; Fabianková, Havel, Novotná, 1999; Mlčáková, 2009; Fasnerová, 2018).

Ďalšie kvalitatívne ukazovatele písma poukazujú na to, že úprava vo všetkých troch vzorkách písma dosahuje u pravákov stupeň vyšší ako 2,50. U dominantne l'avorukých je najnižšia hodnota nameraná v troch vzorkách písma 1,90 a zároveň nepresahuje hodnotu 2,20. V rámci čitatel'nosti dosiahli praváci najpozitívnejšiu priemernú hodnotu vo vzorke prepisu 1,75 a najnegatívnejšiu 2,75 v diktáte. Ak nazrieme na výkon l'avákov, nachádzame najlepšie čitatel'nú vzorku taktiež medzi prepismi, so stupňom 1,50 , ostatné dve hodnoty sú na úrovni 2 . stupňa.

O jednot'ažnosti písania hovoríme vtedy, ked' sú grafémy písané jedným t’ahom, bez prerušenia. Spomínanú zásadu uplatňujeme vo všetkých písmenách malej abecedy, okrem grafém x a u, a tých ktoré si vyžadujú písanie diakritických znamienok. V rámci písania písmen vel'kej abecedy rozlišujeme písmená jednot’ažné, dvojt’ažné a trojtažné (Penc, 1968; Šupšáková, 1998; Fabianková, Havel, Novotná, 1999; Mlčáková, 2009; Fasnerová, 2018). Jednot'ažnost' najlepšie rešpektovali žiaci s dominantnou l'avou rukou, ktorí v diktáte získali priemer 1,10 , čo je o 0,30 menej ako u pravákov, ktorých najlepší výkon tvorí vzorka prepisu.

Dodržiavanie liniatúry je medzi pravákmi a l'avákmi odlišné. U dominantne pravorukých nachádzame priemerne namerané hodnoty v intervale 2,40 2,75 , avšak u dominantne pravorukých to je 1,60 - 1,75. Zaujímavým zistením bolo, že obe skupiny mali najväčší problém s dodržiavaním liniatúry v rámci vzorky odpisu.

Ďalším sledovaným kvalitatívnym aspektom bolo dodržanie správneho tvaru písmen. V dnešnej dobe ako popisuje Křivánek a Wildová (1998) sa 
nevyžaduje úzkostlivé napodobňovanie predpísaných tvarov písmen, akceptujú sa aj mierne rozdiely $\mathrm{v}$ tvaroch písmen. Závisí to na každom posudzujúcom čitatel'ovi, avšak mala by byt' dodržaná čitatel'nost' všetkých grafém. Rovnako náročné dodržanie správneho tvaru bolo voboch skupinách, ked’že najhoršie hodnotenie získali obe skupiny v diktáte. U l'avákov sa opätovne preukázal lepší výsledok s hodnotením 2,10 stupňa. Žiaci s dominantnou pravou rukou obstáli s hodnotením 2,50.

Vzhl'adom na odlišnost' hodnotenia úmernosti, môžeme povedat', že pre žiakov s mentálnym postihnutím, ktorí tvorili našu výskumnú vzorku bolo najnáročnejšie dodržiavanie úmernosti u písmen s hornou dížkou. Žiaci, dominantne pravorukí dosiahli najväčšiu odchýlku v priemere 2,00 vo vzorke prepisu a diktátu. Naopak, dominantne l'avorukí dosiahli najväčšiu odchýlku vo vzorke odpisu. Najnižšia priemerná odchýlka bola zaznamenaná v odpise pravákov v hodnote 1,00. Opačná situácia nastala pri dodržiavaní úmernosti písmen s dolnou dížkou, kde l’aváci, oproti pravákom dosiahli nižšiu odchýlku, konkrétne 1,10 a praváci 1,70.

Nami zvolená výskumná vzorka vykazuje rozdiely v kvalite písomného prejavu medzi žiakmi s mentálnym postihnutím, píšucimi l'avou a pravou rukou. Výsledky poukazujú na fakt, že l'aváci vo svojom písomnom prejave viac uplatňovali zásadu jednot’ažnosti, vo väčšej miere dodržiavali liniatúru, tvar písmen a mali lepšiu úpravu písomného prejavu. Písmo tejto skupiny bolo častokrát viac čitatel'né, musíme však upozornit' na fakt, že v prípade úmernosti písmen s hornou dížkou dosiahli lepší výsledok žiaci píšuci pravou rukou. Oblast' úmernosti písmen bola však pre obe skupiny žiakov s mentálnym postihnutím výrazne problematická.

Výskumná otázka č.2: Aký spôsob písania je preferovaný u l'avákov?

Pomocou pozorovania a fotodokumentácie uvedenej pri každom jednotlivcovi v predchádzajúcej časti kapitoly, sme zistili, že z celkového počtu 10 participantov píšucich l'avou rukou je pät' žiakov píšucich dolným spôsobom a d'alších pät' píše horným spôsobom.

Na obrázku č.1 prezentujeme ako príklad žiačku s dominantnou l'avou rukou preferujúcou horný spôsob písania. Úchop písacieho náčinia je správny, avšak žiačka svoju ruku ohýba v zápästí a píše tzv. hákovitým spôsobom horným spôsobom písania, tzn. nedodržiava odporúčanú metodiku písania l'avákov.

Vodička (2008) spozoroval, že l'aváci sa prikláňajú k hornému spôsobu písania, ktoré je im prirodzenejšie. Z nášho pozorovania však vyplýva, že polovica participantov používala horný a druhá polovica dolný spôsob písania. Výsledky nášho zistenia sa približujú $\mathrm{k}$ hodnotám nameraných vo výskume vykonanom u intaktných žiakov (Peachey, 2004). 

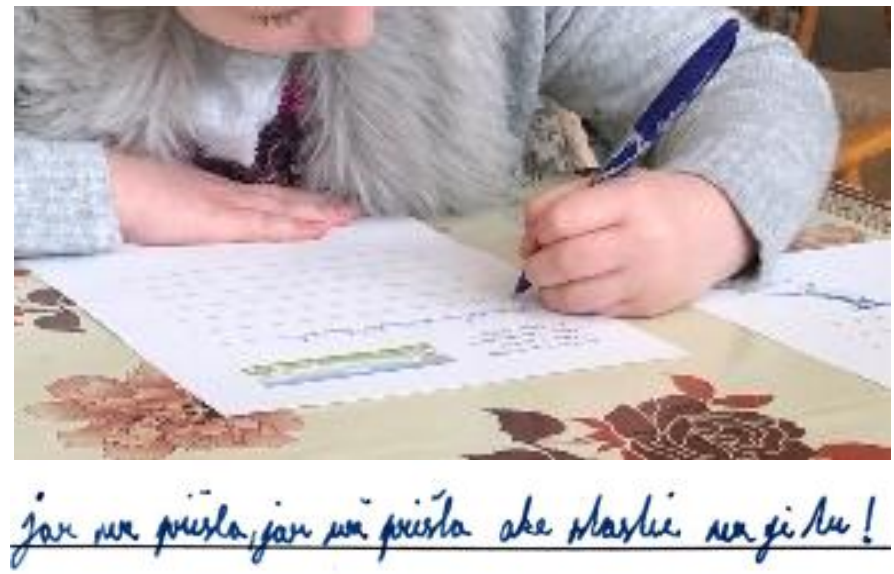

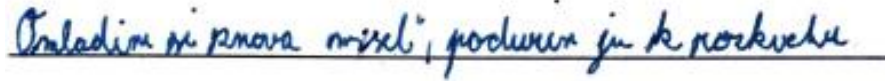

Obrázok 1 Žiačka písúca horným spôsobom písania a jej grafický prejav (prepis)

Výskumná otázka č. 3: Do akej miery dodržiavajú žiaci pri písaní technické požiadavky?

$\mathrm{K}$ najčastejším chybám $\mathrm{v}$ rámci dodržiavania technických požiadaviek patrí zlá poloha trupu. Až u sedemnástich žiakov nachádzame nedostatky v správnom postavení opornej sústavy, čo sa následne prenáša do písomného prejavu žiaka. Len u troch žiakov, z ktorých je jeden s dominantnou pravou rukou a dvaja s dominantnou l'avou rukou, sa preukázalo správne držanie tela.

Spolu s predchádzajúcou požiadavkou úzko súvisí aj poloha dolných končatín. Zistili sme, že žiaci majú často pri písaní nohy podsunuté pod stoličkou a v členkoch prekrížené alebo chodidlá inak umiestnené na častiach stoličky. Ďalším frekventovaným prípadom je náklon trupu vpred, podsadenie panvy s kolenami do strán. Z našej výskumnej vzorky len pät' žiakov dodržalo správnu polohu dolných končatín pri písaní. Z piatich boli štyria praváci a jeden l'avák. Výrazným nedostatkom pri písaní bolo postavenie hlavy. Desat' žiakov z ktorých bolo šest' l'avákov a štyria praváci, dodržalo správnu vzdialenost' hlavy od podložky. Častým javom bol aj nesprávny, či nedostatočný náklon hlavy nad podložkou, vyskytujúci sa spoločne s nesprávnym držaním tela. Správnu súčinnost' horných končatín preukázalo pri písaní 16 participantov, polovica z nich boli l'aváci. Ďalšou pozitívne hodnotenou technickou požiadavkou bolo stabilné sedenie, pri ktorom žiaci sedeli na väčšej časti sedacej plochy stoličky. O niečo lepšie žiaci dodržali správny úchop písacieho nástroja. Z celkovej výskumnej vzorky preukázalo 14 participantov správny štipkový úchop, medzi ktorými bolo rovnaké zastúpenie žiakov pravorukých aj l'avorukých. K nesprávnemu držaniu radíme silný úchop, kedy je ukazovák prehnutý, čím sa vytvára príliš silné a pre žiaka vyčerpávajúce písanie. Okrem spomenutého sa vo výskume

XLinguae, Volume 12, Issue 4, October 2019, ISSN 1337-8384, eISSN 2453-711X 
vyskytlo držanie, kedy ukazovák pri písaní aktívne nespolupracoval, písadlo bolo oň len opreté. Vyskytlo sa držanie písomného náčinia, v ktorom bol palec vo vrchnej pozícii a prekrýval pero z hornej časti.

\section{Záver}

Empirickým výskumom sa preukázalo, že v našej výskumnej vzorke existuje rozdiel v kvalite písomného prejavu žiakov s mentálnym postihnutím rôznej dominancie horných končatín.

U žiakov oboch skupín sme zaznamenali najväčšiu úspešnost' vo vzorkách prepisu. Medzi kategórie, ktoré žiakom robili najmenšie t’ažkosti radíme jednot'ažnost'. Naopak najnižšiu úspešnost' sme pri vyhodnotení spozorovali $\mathrm{v}$ dodržiavaní správneho tvaru písmen. Tvary jednotlivých samohlások, ale aj spoluhlások strácali na kvalite, čo sa $\mathrm{v}$ konečnom dôsledku preukázalo na st’ažení schopnosti prečitat' jednotlivé vzorky písma. K zaujímavým výsledkom sme dospeli $\mathrm{v}$ kategórii úmernosti písmen. U dominantne lavorukých žiakov bola vyššia úspešnost' $\mathrm{v}$ písaní písmen s dolnou dížkou, praváci dosiahli lepší výsledok $\mathrm{v}$ písmenách $\mathrm{s}$ hornou dížkou. Z hl’adiska vyrovnanosti hodnôt môžeme povedat', že l'avorukí participanti výskumu dosiahli v rámci úmernosti písmen konzistentnejšie výsledky.

Vo vel'kosti písmen nezaznamenávame koreláciu medzi oboma skupinami participantov. V kategórií sklonu sa preukázalo, že priemerný sklon participantov píšucich l'avou rukou je bližšie k odporúčaným hodnotám intervalu. Často opakovaným a znepokojujúcim javom pri vyhodnocovaní technických požiadaviek písania bola nesprávnea poloha tela pri písaní. Celá váha tela spočívala na lakt’och pisatel'a, hlava $\mathrm{v}$ týchto prípadoch bola nadmerne sklonená, čím sa narušila vzdialenost' hlavy od podložky. Správne postavenie trupu pri písaní mali len traja participanti, z ktorých dvaja boli dominantne l'avorukí, a jeden pravoruký. Vo väššine prípadov tento trend sprevádzalo aj zlé umiestnenie dolných končatín. Medzi pozitívne zistenia môžeme zaradit' väčšinový výskyt správneho umiestnenia horných končatín na podložke.

Výsledky hodnotenia správneho úchopu u celkovej vzorky participantov hovoria, že štrnást' žiakov dodržalo správny úchop. Prekvapivo sa preukázalo, že polovicu z nich tvorí skupina pravákov a rovnaká čast' je zastúpená l’avákmi.

Vzhl’adom na roztrieštenost' odborných názorov, nás zaujímala frekvencia výskytu horného spôsobu písania. Pri podrobnom zameraní sa na skupinu žiakov s dominantnou l'avou rukou, sme zistili, že až 5 žiakov preferuje dolný (odporúčaný) spôsob písania a zvyšná polovica píše horným (nad linkou) spôsobom. Podl’a výsledkov výskumu môžeme povedat', že u žiakov píšucich l'avou rukou je potrebné zaviest' istú jednotnost', v ponímaní dodržiavania pravidiel stanovených metodikou písania. Je však otázne, či existujúca metodika písania bude uplatnitel'ná u všetkých l’avorukých žiakov.

\section{Bibliographic references}

AVANTE, E. 2009. Pisomny prejav ziakov 4. rocnika specialnej zakladnej skoly - A variant. Bratislava : PdF UK, 140 p. 
DRNKOVA, Z. - SYLLABOVA, R. 1991. Zahada levactvi a pravactvi. 2.vyd. Praha : Avicenum, 88 p. ISBN 80-201-0119-6.

FABIANKOVA, B. - HAVEL J. - NOVOTNA, M. 1999. Vyuka cteni a psani na 1. stupni zakladni skoly. Brno: Paido, 1999, 81 p. ISBN 80-8593164-8.

FASNEROVA, M. 2016. Jednotazne linearni pismo v kontextu pisarske gramotnosti. Olomouc: Hanex. 148 p. ISBN 978-80-7409-053-0.

FASNEROVA, M. 2018. Prvopocatecni cteni a psani. Praha: Grada, 288 p. ISBN 978-80-271-0289-1.

HEALEY, J. M. 2002. Levaci a jejich vychova. Praha: Portal, 111 p. ISBN 80-7178-701-9.

HEALEY, J. M. 2015. Levaci a jejich vychova. 2. vyd. Praha: Portal, 111 p. ISBN 978-80-262-0855-6.

HOLLE, H. 2011. Laterality in the rubber hand illusion. In: Laterality: Asymmetries of Body, Brain and Cognition, vol. 16, pp. 174 -187. DOI: 10.1080/13576500903483515.

KRIVANEK, Z. - WILDOVA, R. 1998. Didaktika provopocatecniho cteni a psani. Praha: Pedagogicka fakulta UK, 1998. ISBN 80-86039-55-2.

KRISTANOVA, L. 1991. Diagnostika laterality a metodika psani levou rukou. Hradec Kralove: Gaudeamus, 43p. ISBN 80-7041-384-0.

MATEJCEK, Z. - ZLAB, Z. 1972. Zkouska laterality. Brno: Psychodiagnostika.

MLCAKOVA, R. 2009. Grafomotorika a pocatecni psani. Praha: Grada Publishing, 2009. 224 p. ISBN 978-80-247-2630-4.

ORDODY, D. 2008. Pisomny prejav ziakov 3. rocnika specialnej zakladnej skoly - A variant: diplomova praca. Bratislava: PdF Univerzita Komenskeho, 2008. 154 p.

PAVLIS, P. 1989. Materinsky jazyk s teoriou vyucovania I: Pre specialne skoly. Bratislava: PdF Univerzita Komenskeho. ISBN 80-223-0064-0.

PEACHEY, 2004. Left-handedness: A writing handicap? Visible Language, vol. 38, pp. 262-288.

PENC, V. 1961. Metodika psani. Vyd. 4. Praha: Statni pedagogicke nakladatelstvi, $91 \mathrm{p}$.

PRINOSILOVA, D. 1997. Vybrane okruhy specialne pedagogicke diagnostiky a jeji vyuziti v praxi specialni pedagogiky. Brno: Masarykova Univerzita, 89 p. ISBN 80-210-1595-0.

SILLAMY, N. 2001. Psychologicky slovnik. Olomouc: Univerzita Palackeho, 246 p. ISBN 80-244-0249-1.

SOVAK, M. 1971. Metodika vychovy u levaku. Praha: SPN.

SOVAK, M. 1979. Vychova levaku v rodine. Aktualni problemy v specialni pedagogice. Praha: SPN, 116 p. ISBN 14-472-79.

SPACILOVA, H. - SUBOVA, L. 2004. Priprava zaka na psani, rozvijeni grafomotoriky a zrakoveho vnimani. Olomouc: Univerzita Palackeho, 87 p. ISBN 80-7178-942-9.

SYNEK, F, 1991. Zahady levorukosti. Asymetrie u cloveka. Praha: Horizont, 175 p. ISBN 80-7012-054-1.

XLinguae, Volume 12, Issue 4, October 2019, ISSN 1337-8384, eISSN 2453-711X 
SPU, 2016. Vzdelavaci program pre ziakov s mentalnym postihnutim pre primarne vzdelavanie.

SULOVSKA, M. - MILACKOVA, D. 2016. Analysis of the writing skills of students with mild mental disability. In: Slavonic Pedagogical Studies Journal: The Scientific Educational Journal, vol. 7. n. 2, pp. 354-362. ISSN 1339-8660. doi: 10.18355/PG.2016.5.2.354-362

SUPSAKOVA, B. 1998. Pismo a pisanie. Bratislava: Univerzita Komenskeho, 219 p. ISBN 80-223- 1293-2.

VALENTA, M. - MICHALIK, J. - LECBYCH, M., a kol. 2018. Mentalni postizeni. Vyd. 2. Praha: Grada, 392 p. ISBN 978-80-271-0378-2.

VODICKA, I. 2008. Nechte levaky drapat. 1. vyd. Praha: Portal, 104 p. ISBN: 978-80-7367-479-3.

ZIKL, P. - BENDOVA, P. 2014. Dite s mentalnim postizenim ve skole. Praha: Grada, 140 p. ISBN 978-80-2473-854-3.

Words: 4620

Characters: 32876 (18,26 standard pages)

PaedDr. Monika Šulovská, PhD.

Prof. PaedDr. Alica Vančová, CSc.

Mgr. Natália Neupauerová

Department of Special Education,

Faculty of Education Comenius University

Račianska 59, Bratislava 81334

Slovakia

sulovskamonika@gmail.com 